\title{
Classroom Participation: Nursing Students Perspective Paper Critique
}

\author{
Ibrahim Mohammad Hatamleh ${ }^{1} \&$ Hashem Ali Issa Almuslamani ${ }^{1}$ \\ ${ }^{1}$ College of Administrative Sciences, Applied Science University, 23East Al-Ekir, Kingdom of Bahrain \\ Correspondence: Ibrahim Mohammad Hatamleh, College of Administrative Sciences, Applied Science University, \\ 23East Al-Ekir, Kingdom of Bahrain.
}

Received: June 7, 2020

Accepted: September 22, 2020

Online Published: September 23, 2020

doi:10.5430/ijhe.v9n6p236

URL: https://doi.org/10.5430/ijhe.v9n6p236

\begin{abstract}
This article aims to critique a published paper according to UK professional Standard Framework (UKPSF). The critiqued paper in this article was written by Loftin, Davis, and Hartin (2010) that provide clarity and meaning for classroom participation from the nursing student perspective at West Texas A\&M University. The article shows that the title of the published paper was not reflected the purpose of the study, the literature review, and the results. Besides that, the critiqued paper provided clarity and meaning of the classroom participation, but the results explained the factors behind the reluctance of the student in the participation. This article contributes to the body of the knowledge in higher education and provides valuable facts about the practices of instructors and peers that lead to improving the students' participation.
\end{abstract}

Keywords: classroom participation, UK professional Standard Framework (UKPSF)

\section{Introduction}

Classroom participation plays a key role in improving the teaching and learning process in higher education (Norris, 2014). In particular, classroom participation could enhance mastery of content and critical thinking skills of the students (Kennedy, 2007) which is considered as the most significant teaching aim and a substantial indicator of the higher education quality (Gojkov, Stojanović, and Rajić, 2015). This topic has gained the scholar's attention such as Loftin, Davis, and Hartin (2010), who wrote their article 'Classroom participation: A student perspective' published by Elsevier Inc. in 2010.

Loftin, Davis, and Hartin (2010) provided clarity and meaning for classroom participation from a nursing student perspective. To explore this fact, Loftin, Davis, and Hartin (2010) - authors of paper chosen to be critiquedconducted the study at West Texas A\&M University in the United States of America. Loftin, Davis, and Hartin (2010) exploited an exploratory content analysis approach. 11 baccalaureate nursing students were participated and interviewed in the study voluntarily. Loftin, Davis, and Hartin (2010) collected data that were analyzed using the method described by Wood, Priest, and Roberts (2002) who debated using qualitative content analysis and narrative analysis by using an illustrative example.

\section{Literature Review}

The researchers argued the importance of classroom participation that the nursing students need to facilitate the delivery of competent and safe care. The researchers referred to Weaver and Qi (2005) to support their notions and to highlight the significant problem of the research. According to Weaver and Qi (2005), the students are often reluctant to participate in the classroom, and this reluctance effect negatively on critical thinking and retention of the information. After referring to Fassinger (1995) and Weaver, and Qi (2005), three types of classroom participation were identified by the researchers. These three types are volunteer participation, graded participation, and required participation. The researchers depended on Crombie, Pyke, Silverthorn, Jones, and Piccinin (2003) and Zhou, Knoke, and Sakamoto (2005) to show several facts such students speaking English as a second language participate less than their peers in the classroom and the larger class size has smaller rates of participation

\section{Findings}

The critiqued article that prepared by Loftin, Davis, and Hartin (2010) tried to find out what encourages the students to participate in the classroom. At the same time, the article focused on students' perspectives toward classroom situation aspects that facilitate and inhibit classroom participation. In this context, the exploratory content analysis study revealed four facts. Firstly, the faculty has influences on the students' participating in the classroom. In 
particular, the students looked to the instructor for visual and verbal cues before voluntary participation. For example, the students showed that the instructor who does not talk too fast, make eye contact, display positive body language, walk around the room and do not asking question after students question in return is facilitating and encouraging the student to participate (Loftin, Davis and Hartin, 2010). This finding agreed with Anaya and Cole (2001) who revealed imperially that the instructor has a positive relationship with students' participation.

Secondly, the study of Loftin, Davis, and Hartin (2010) stated that students were affected by their peers. In specific, students reluctant to participate due to their negative feedback from the classmate. Additionally, students looked to their classmates for verification or support. This fact consistent with Smith et al. (2009) when they showed that the peer influences the student's participation and involvement A4. Thirdly, the students indicated that the physical environment of the classroom played a vital role in whether or not they felt capable of participation A4. Furthermore, the student unwilling to participate in a larger classroom setting. Finally, the study showed that the student's personality affected their participation and interaction with their classmate. These findings agreed with (Mahoney, Cairns, and Farmer, 2003) who indicated a significant relationship between personality and participation in the classroom and the students stated that they do not like to talk in public and they prefer to seek verifications form their peers. At the end of the article, the researchers recommended future research to examine the benefits of classroom configuration on students learning which might increase participation. Besides that, the article has no included any limitation regarding the sample size, time, or information related to the concerned topic.

\section{Evaluating Insight}

As a valuable step towered critiquing published literature, Coughlan, Cronin, and Ryan (2007) debated that the evaluation of weakness and limitation of the article could be implemented into two sections. The first section is the elements influencing the believability of the research and the second section is the elements influencing the robustness of the research.

\subsection{Elements Influencing the Believability of the Research}

The article was presented for very special people who are interested in teaching in higher education. Regarding authors; the brief google search showed the three authors work as instructors of nursing at West Texas A\&M University. Three of them have varied research and academic experiences. In particular, their research interests include nursing education (Loftin et al., 2012, 2013). Their educations, work experiences, and publications showed that they are qualified enough to present this article. The title of the article is clear without any implicit argument. However, it could not specify the content. Classroom participation is a broad topic and included various subjects (Rocca, 2010). Therefore, this title could be more narrowed to reflect the content, which focused on four factors that influence the students' participation and reduced their reluctance. Additionally, the text of the article was written in clear language, logical, and explicitly argument. Also, the article followed the normal style for exploratory content analysis research (Prasad, 2008; Wood and Welch, 2010)

\subsection{Elements Influencing the Robustness of the Research}

Although the purpose of the article was identified clearly, the literature review and findings of the content analysis did not compatible or related to this purpose. For example, the authors amid to provide clarity and meaning for the classroom participation, but the most focus of literature review on types of participation, factors that influence on students participating in the classroom. However, the content analysis debated the reluctance of the students inside the classroom (Loftin et al., 2013). Furthermore, the studied factors that were debated in findings have not received enough attention to the authors comparing with another aspect, which was discussed in the literature review. For example, the faculty and interpersonal influences that studied in the findings section have not been debated in the literature review.

Also, the article displayed several facts in the literature review. These facts were presented based on authors' assumptions, which were not supported by evidence and not presented with sufficient debates. These assumptions have been shown in different locations when the authors talk about the participants have received little attention at the undergraduate level, students perceive that they will miss out on important content because of other peer's question or comment, and students who participate in the classroom share common traits. Using evidence such as published theories and surveys can improve the conventional approach in this article. On the contrary, reviewing the concerned literature illustrated that participation topics have been studied before and received the attention of the Schillers and researchers. For example, Crombie et al. (2003) empirically investigated the effects of instructor and the gender of the students on their participation in the classroom in higher education. Moreover, the effects of peer have been studied not just by Weaver and Qi (2005), but also by Dixon, Egendoerfer, and Clements (2009). 
While the purpose of the article was to provide clarity and meaning for classroom participation, it was expected to see extensive debated in the literature review regarding the concept, objectives; underlying theories link classroom participation with different aspects like the faculty, classroom environment, and critical thinking.

Regarding the sample, Creswell (2012) stated that the sample is a subgroup of the target population it was planned to study for generalizing the targeted population. The critiqued article involved 11 students as a sample of the nursing students as the population of the study. Here, it was better for the authors to explain the sampling method and to justify the reason for choosing this number of students (Sekaran, 2003; Creswell, 2012). This justification is important here to give good imprison about the result especially when it is known that the goal of the qualitative method is to produce a generalized theory (Wood and Welch, 2010).

The arguments of the findings and the results of the study were presented logically and consistently. The argument discussed four areas that have influences on the student's participation. These areas faculty influences, other students' influences, environmental influences, and interpersonal influences. The argument of the rustles was supported by facts and examples that surveyed during the qualitative study. Additionally, the four studied areas contained the most important factors that affect the students' participation such as the instructor's practices and peers' behavior.

However, the argument that related to the findings leads to valuable and significant implications, which should be considered to improve classroom participation in higher education. Based on the findings, the authors showed that the instructor is required to encouraging his students to participate by walking around the room, using the eye contact and body language properly, allowing students to talk to each other, and improve the classroom environment through reducing the negative effects of the large size classroom. This implication could be achieved and conducted in the classroom to improve the participation level among the students. Although these valuable implications, the authors stated that the students are required to apply there skills and knowledge learned in the classroom to the world to present safe competent care to patients. This implication was not fully explained and discussed. Simultaneously, this implication should be clear, precise, and flow from the results of the study (Kothari, 2004).

According to Creswell (2012), the qualitative researcher in the education studies suggests possible limitations or weaknesses of the study and makes his recommendations for future research. Hence, the critiqued article recommended that future research should examine the benefits of classroom configuration in both virtual and physicals classroom and student learning. This recommendation was not developed from the limitations of the study and do not flow from the results of the study (Kothari, 2004; Creswell, 2012). Also, this recommendation is not related directly to the participation of the student in the classroom.

\section{Conclusion}

The article was written by Loftin, Davis, and Hartin (2010) to provide clarity and meaning for classroom participation from the nursing student perspective at West Texas A \& M University. This article qualitative study exploited exploratory content analysis. The article divided into many topics such as introduction, review of the literature, methodology, results, implication, and conclusions, and recommendations for future research. The title of the article was not specified and not reflected the purpose of the study, the literature review, and the results. Additionally, the broad purpose of the study has not been covered exactly by the results. In particular, the purpose was to provide clarity and meaning of the classroom participation, but the results explained the factors behind the reluctance of the student in the participation. The results revealed that the students' participation is influenced by several factors related to the instructor, other students, the classroom's environment, and interpersonal factors.

This article contributed to the body of knowledge in higher education. Theoretically, this article provided valuable facts about the practices of instructors and peers that lead to improving the students' participation. At the same time, it has a significant contribution to the practitioners in higher education especially when the authors argued the role of the instructor in enhancing the student's participation.

Although the weakness of the article, it could believe that the results of the content analysis provide a solid base for action research in the future. This article pointed out the most significant problem that faces many instructors in higher education. This study could explore the most impotent reasons behind the reluctance of students in classroom participation. Hence, the action research here is significant to improve the student participant not only by reducing the effects of the four inflicting factors that were studied in the article but also through intervening new ideas and creative programs such as employing educational videos in the classroom chosen by the instructors and students. 


\section{References}

Anaya, G., \& Cole, D. G. (2001). Latina/o student achievement: Exploring the influence of student-faculty interactions on college grades. Journal of College Student Development, 42(1), 3-14.

Coughlan, M., Cronin, P., \& Ryan, F. (2007). Step-by-step guide to critiquing research. Part 1: quantitative research Michael. British Journal of Nursing, 16(11), 658-663. https://doi.org/10.12968/bjon.2007.16.11.23681

Creswell, J. W. (2012). Educational Research. 4th ed. Boston, Pearson Education. https://doi.org/10.4236/jss.2018.67006

Crombie, G., Pyke, S. W., Silverthorn, N., Jones, A., \& Piccinin, S. (2003). Students' Perceptions of Their Classroom Participation and Instructor as a Function of Gender and Context. The Journal of Higher Education, 74(1), 51-76. https://doi.org/10.1353/jhe.2003.0001

Dixon, J. K., Egendoerfer, L. A., \& Clements, T. (2009). Do they really need to raise their hands? Challenging a traditional social norm in a second grade mathematics classroom. Teaching and Teacher Education, 25(8), 1067-1076. https://doi.org/10.1016/j.tate.2009.04.011

Fassinger, P. A. (1995). Understanding Classroom Interaction. Journal of Higher Education, 66(1), 82-96. https://doi.org/10.2307/2943952

Gojkov, G., Stojanović, A., \& Rajić, A. G. (2015). Critical Thinking of Students - Indicator of Quality in Higher Education. Procedia - Social and Behavioral Sciences, 191(2012), 591-596. https://doi.org/10.1016/j.sbspro.2015.04.501

Kennedy, R. (2007). In-Class Debates: Fertile Ground for Active Learning and the Cultivation of Critical Thinking and Oral Communication Skills. International Journal of Teaching and Learning in Higher Education, 19(2), 183-190.

Kothari, C. R. (2004). Research Methodology: Methods and Techniques. New Delhi, New Age International Publication.

Loftin, C., Davis, L. A., \& Hartin, V. (2010). Classroom Participation: A Student Perspective. Teaching and Learning in Nursing, 5(3), 119-124.

Loftin, C., Hartin, V., Branson, M., \& Reyes, H. (2013). Measures of cultural competence in nurses: An integrative review. The Scientific World Journal, 2013. https://doi.org/10.1016/j.teln.2010.02.004

Loftin, C., Newman, S. D., Dumas, B. P., Gilden, G., \& Bond, M. Lou. (2012). Perceived Barriers to Success for Minority Nursing Students: An Integrative Review. ISRN Nursing, 2012, 1-9. https://doi.org/10.5402/2012/806543

Mahoney, J. L., Cairns, B. D., \& Farmer, T. W. (2003). Promoting interpersonal competence and educational success through extracurricular activity participation. Journal of Educational Psychology, 95(2), 409-418. https://doi.org/10.1037/0022-0663.95.2.409

Norris, S. (2014). Learning Tacit Classroom Participation. Procedia - Social and Behavioral Sciences, 141, 166-170. https://doi.org/10.1016/j.sbspro.2014.05.030

Prasad, B. D. (2008). Content Analysis A method in Social Science Research. In: Lal Das, D.K, and Bhaskaran. Research Methods for Social Work. New Delhi, Rawat, pp. 173-193.

Rocca, K. A. (2010). Student participation in the college classroom: An extended multidisciplinary literature review. Communication Education, 59(2), 185-213. https://doi.org/10.1080/03634520903505936

Sekaran, U. (2003). Research Methods for Business: A Skill Building Approach. 4th edn, Journal of Chemical Information and Modeling. 4th ed. New York, John Wiley \& Sons. https://doi.org/10.4236/ce.2012.326132

Smith, M. K., Wood, W. B., Adams, W. K., Wieman, C., Knight, J. K., Guild, N., \& Su, T. T. (2009). Why peer discussion improves student performance on in-class concept questions. Science, 323(5910), 122-124. https://doi.org/10.1126/science.1165919

Weaver, R. R., \& Qi, J. (2005). Classroom Organization and Participation: College Students' Perceptions. The Journal of Higher Education, 76(5), 570-601. https://doi.org/10.1353/jhe.2005.0038

Wood, L., Priest, H., \& Roberts, P. (2002). An overview of three different approaches to the interpretation of qualitative data. Part 1: theoretical issues. Nurse Researcher, 10(1), 30-42. 
Wood, M., \& Welch, C. (2010). Are "Qualitative" and "Quantitative" Useful Terms for Describing Research? Methodological Innovations Online, 5, 56-71. https://doi.org/10.4256/mio.2010.0010

Zhou, Y. R., Knoke, D., \& Sakamoto, I. (2005). Rethinking silence in the classroom: Chinese students' experiences of sharing indigenous knowledge. International Journal of Inclusive Education, 9(3), 287-311. https://doi.org/10.1080/13603110500075180

\section{Copyrights}

Copyright for this article is retained by the author(s), with first publication rights granted to the journal.

This is an open-access article distributed under the terms and conditions of the Creative Commons Attribution license (http://creativecommons.org/licenses/by/4.0/). 